ACTA UNIVERSITATIS LODZIENSIS

FOLIA LITTERARIA POLONICA 5(35) 2016

http://dx.doi.org/10.18778/1505-9057.35.12

Natalia Kowalska*

\title{
The American Broadcast My Lobotomy as an Example of a Radio Feature in the West
}

Reportage can be basically identified as a non-fiction genre, no matter if it is presented by means of press, television or radio. The word "basically" is used here, as representations of the genre on radio stations in Western Europe, the United States and Australia often include added fictional elements. Reportage, which is based on a real story, however, enriched with fictional content is called a radio feature (a radio documentary). The term, even though in Poland it is not translated from English, has established itself within Polish science, and has been used by scholars and radio reporters for over a decade. The term is used, among others, by professor Elżbieta Pleszkun-Olejniczakowa, Jerzy Tuszewski and Janina Jankowska. It is also used by Kazimierz Wolny-Zmorzyński in relation to the press genre.

The American radio feature by David Isay entitled My Lobotomy is the example on the basis of which I would like to present this non-fiction radio broadcast. In this work, the protagonist is also the narrator, he reads out text sequences, which somehow lead the recipient through the story. The introduction of a narrator makes My Lobotomy a feature broadcast and not a typical radio reportage, to which the Polish recipient is accustomed. The aim of this article is to present the relations between a feature and a radio reportage in Polish and foreign radio stations.

\section{The radio feature and the radio reportage on Polish radio}

Many radio scholars focus on the radio reportage in their analysis, however Kazimierz Wolny writes that "since the interwar period till this day ... a precise definition of reportage has not been invented. There are as many descriptions

* MA, e-mail: natalia.t.kowalska@gmail.com; The University of Lodz, Faculty of Philology, Department of Journalism and Public Communication; ul. Pomorska 171/173, 90-236 Łódź. 
based on different criteria as there are authors and theoreticians"1. The diversity and multiplicity of works allows us, however, to distinguish at least two criteria, two distinctive features characterising the genre no matter the medium in which it appears. These criteria seem to be its documentary nature - it is perhaps applicable to any reportage - and, less universal, a kind of "suspension" between journalism and art. Helena Wiegner wrote that "reportage fulfils all functions of mass media communications and some functions of art"2. Krzysztof Kąkolewski's claim seems also exceptionally accurate as it states that "it is the requirement of authenticity which distinguishes reportage from fiction, and it is the beauty of form which distinguishes it from journalism ${ }^{3 / 6}$ [emphasis - N.K.]. The context of these reflections points out that they mostly refer to the press reportage, a written form, however, they can also be applied to audio reports. As Kinga Klimczak the radio reportage researcher - states, reportage is:

an audio work, which is always based on the truth about an event and people [...] On the one hand, reportage is characterised by objectivism in the sense of an honest record of events, on the other hand, however, by subjectivism understood as the influence of the author on the way it is presented. A phonically registered reality is composed according to the rules of drama in a more or less artistic way, depending on how the facts are transformed by the author ${ }^{4}$.

Zbigniew Bauer puts reportage among the informational genres, indicating that informing about real events in a substantive way ${ }^{5}$ is the primary function of reportage. Kazimierz Koźniewski has a similar opinion. He states that "reportage conveys the truth of the day to a reader by means of any artistic measure, excluding fiction" ". Thus Koźniewski also claims that communicating facts is the basis of reportage. What is more, it is considered unacceptable to use fabricated elements, even if they are to serve for a more vivid or more comprehensive presentation of the subject.

\footnotetext{
${ }^{1}$ K. Wolny, „Reportaż - jak go napisać?”, Fosze, Rzeszow 1996, p. 12.

${ }^{2}$ H. Wiegner, „Funkcja form reporterskich w «Programie dla Zagranicy» Polskiego Radia”, Wydawnictwa Radia I Telewizji, Warsaw 1972, p. 20.

${ }^{3}$ K. Kąkolewski, „Reportaż” [Entry], in: „Słownik literatury polskiej XX wieku”, ed. A. Brodzka et al., Zakład Narodowy im. Ossolińskich, Wroclaw 1993, p. 932.

${ }^{4}$ K. Klimczak, „Reportaże radiowe o krzywdzie i cierpieniu”, Wydawnictwo Primum Verbum, Lodz 2011, p. 52.

${ }^{5}$ Z. Bauer, „Gatunki dziennikarskie”, in: „Dziennikarstwo i świat mediów”, ed. Z. Bauer, E. Chudziński, Universitas, Cracow 2010, pp. 143-173.

${ }^{6}$ K. Koźniewski, „Rzeczywistość i fikcja”, in: S. Baczyński, A. Kijowski, „Pisma krytyczne", Państwowy Instytut Wydawniczy, Warsaw 1963, p. 404, as cited in: K. Wolny-Zmorzyński, A. Kaliszewski, W. Furman, „Gatunki dziennikarskie. Teoria - praktyka - język”, Wydawnictwa Akademickie i Profesjonalne, Warsaw 2006, p. 57.
} 
However, reporters, both in Poland and in other countries, produce works in which, apart from the authentic sounds and characters, there are also imaginary elements. Some scholars accept this: Elżbieta Pleszkun-Olejniczakowa adduces such occurrences in her work entitled Muzy rzadko się do radia przyznaja [The Muses Do Not Often Acknowledge the Radio] on reportage and radio plays. In press reportages "Jerzy Lovell [...] accepted a considerable share of fiction" When it comes to radio reportage Józef Mayen distinguished the drama reportage, defining it as "something similar to [...] a semi-authentic reportage and a semiimprovised radio play".

The radio feature is a genre which stands in opposition to reportage - a purely informative genre focused on facts. Even though the essence of the form consists of authentic characters or events, authors of radio features, in order to present them, also use imaginary, fictional and creative elements. The feature, which was created in the West, is the most popular form of reportage there. Eugen Kurt Fischer wrote that describing a feature as "a documentary communication" or simply "a documentary" diminishes the importance of the "poetic component of the new form". A similar standpoint is presented by Jens Jarisch - a contemporary author and radio producer. He defines the radio feature as "an audio formation which allows one to experience events and the relationships between them afresh" ${ }^{\prime 10}$. For Jarisch the essence of the genre lies in its duality - the content is documentary, however, the form is artistic. From a broader perspective, a feature can consist of anything that is audible, as well as of silence ${ }^{11}$.

A radio feature - similarly to the "classic" radio reportage - is perceived and defined differently in the West and even among Polish radio reporters. Irena Piłatowska - a great reportage author, winner of several awards granted in Poland and abroad, and since 2004 director of the Reportage and Documentary Studio at Polskie Radio S.A. (Polish Radio) - states that the distinguishing qualities of a radio feature are the elaborate artistic form and the focus on the creative act, especially the attention to the acoustic level. At the same time she adds that "feature means the same as artistic reportage or, as it was called in Poland, literary reportage"12. Piłatowska's predecessor in the post at the Reportage and Documentary Studio,

${ }^{7}$ E. Pleszkun-Olejniczakowa, „«Muzy rzadko się do radia przyznają». Szkice o słuchowiskach i reportażach radiowych", Wydawnictwo Primum Verbum, Lodz 2012, p. 94.

${ }^{8}$ J. Mayen, as cited in: E. Pleszkun-Olejniczakowa, op. cit., p. 94.

${ }^{9}$ E.K. Fischer, "Hoerpiel. Form und Funktion" [on-line], http://www.mediaculture-online. de/Autoren_A-Z.253+M53913aff3f5.0.html [access: 13.03.2013]. All translations in Polish, if not stated otherwise, come from the author of the article. See also: J. Bachura, "Feature - the marriage of Fact and Fiction", in: "Radio - Community, Challenges, Aesthetics", [Print].

${ }^{10} \mathrm{~J}$. Jarisch, "Was ist eigentlich ein Feature?" [on-line], http://www.yeya.de/journal/faq [access: 4.02.2013].

${ }^{11}$ Ibid.

${ }^{12}$ K. Klimczak, op. cit., p. 68. 
a winner of the three most important audio festivals, as well as of many other awards and prizes - Janina Jankowska - had a slightly different understanding of the term. She used it in relation to a form of radio reportage which uses all radio means allowing creation, as long as it remains non-fiction. The author of Polski Sierpien also firmly claimed that Peter Leonhard Braun from Sender Freies Berlin (SFB) - the creator of the International Feature Conference (IFC) $)^{13}$ - was the author of the term. However, another prominent radio journalist, Jerzy Tuszewski - who for many years worked for Polskie Radio, among other stations, at Polskie Radio Programme II where he was the host of Studio Form Dokumentalnych [Studio of Documentary Forms], and who is the author of books written from the perspective of a practitioner - in one of his works strongly disputes Jankowska's judgement, claiming that Braun is not the "father" of the term. He was only the director of the very first radio unit in the world which used the term in their business name ${ }^{14}$.

Klimczak associates the term feature with everything which is "most artistic, valuable and elitist in reportage" 15 . The scholar also quotes Adam Budzyński's stance - the "Antena" journalist - who states that there is the possibility of a specific introduction of fiction through a reconstruction of plausible events, which, nonetheless, did not occur in reality, an introduction of the "dialogues, which could exist between real people, but which were not recorded because they simply did not happen"16. What is more, Adam Budzyński defines the radio feature as "an intermediate measure between reportage and a radio play, which combines the documentary and fiction elements into an organic, dramatized entity"17. The border between the facts and creation is blurred, and it gives the authors of the genre the ability to use the experience of reportage and radio plays. In a feature a dialogue is opened between what is real and what is invented. Conveying facts supported with fictional elements and invented situations, which are, nonetheless, plausible, plasticises the communication. All artistic measures are allowed, and the importance of this is emphasised by Piłatowska - when talking about the qualities distinguishing the radio feature from the radio reportage, she talks about its elaborate artistic form and the attention to the acoustic level ${ }^{18}$.

${ }^{13}$ E. Pleszkun-Olejniczakowa, „Reportaż to gra uczuć i emocji. O reportażach radiowych współczesnych twórców Polskiego Radia”, in: „Media studies. Refleksja nad stanem obecnym”, ed. K. Stępnik, M. Rajewski, Wydawnictwo Uniwersytetu Marii Curie-Skłodowskiej, Lublin 2008, p. 371.

${ }^{14}$ J. Tuszewski, „Paradoks o sławie i dźwięku. Rozważania o sztuce radiowej”, Wydawnictwo Adam Marszałek, Torun 2002, pp. 32-38.

${ }^{15}$ K. Klimczak, op. cit., p. 70

16 Ibid.

${ }^{17}$ A. Budzyński, „Feature - gatunek otwarty”, Antena 1983, No. 23, p. 14.

${ }^{18}$ K. Klimczak, op. cit., p. 68. 


\section{David Isay and Piya Kochhar's My Lobotomy as an example of a radio feature in the West}

Western documentary productions more and more often depart from the form which conveys only authentic information, showing a tendency to produce works in which fiction complements the story. The German, English or American reportage is what in Poland is understood as a feature. The process of inventing elements in quasi-documentary forms increases the aesthetic values of the work, and allows the authors to present the issue more comprehensively.

The American feature My Lobotomy was produced in 2005 as a part of the Sound Portraits Productions project. The project was aimed at creating radio documentaries, which combined would create an American history base. When it comes to the spoken American history the successor of the Sound Portraits is StoryCorps, which also works under the supervision of David Isay. The difference between these two projects is in the form in which the recordings are tracked: Sound Portraits consists of works which are a dozen or several dozen minutes long and which fall within the ambit of the radio feature and radio reportage genres $^{19}$, whereas StoryCorps consists of only a few-minute long recordings of New Yorkers' conversations or confessions.

In My Lobotomy by David Isay and Piya Kochhar, the protagonist is also the narrator who "leads" the listener through his story. The narrative sequences, however, are not spontaneously spoken during the recording, and this plays a major role in my distinction, as I treat this broadcast as a feature. There are characters who exist in the real world, and the told story did happen, nonetheless, what distinguishes My Lobotomy is the way it presents the events.

It is a story about Howard Dully who in the 1960s underwent a lobotomy procedure conducted by means of an "ice pick". Lobotomy is a neurosurgical procedure which consists of cutting the connections between the frontal lobe and the cerebral cortex. A doctor would reach the patient's brain with surgical instruments through an eyeball. The procedure was employed in order to cure mental disorders. The first scene of the broadcast presents the commonness of the procedure. The image of Walter Freeman conducting a lobotomy was created on the basis of statements of a few elderly people: "[Patricia Derian] We went into a room. [...] [Helen Culmer] He had an instrument. To me, it looked like a nail. A great big nail. [...] [Frank Freeman] It looked like a screwdriver.

The people who speak at the beginning are other patients of the same doctor who conducted Dully's procedure. Their memories are supported by the comments of three doctors. From these the listener gets to know that the described

\footnotetext{
${ }^{19}$ Collected under a general name "radio documentaries".
} 
instrument is the actual "ice pick". The third doctor explains that it is the colloquial name for a surgical instrument. After the description of the procedure, the music, which accompanied the speech, fades and a poor quality recording follows: "This is Walter Freeman, MD, PhD. I am 72 years old now". There is another overlapping utterance: This is Howard Dully. In 1960, when I was 12, I was lobotomized by this man, Dr. Walter Freeman". The narrator speaks directly to the recipient: "Until this moment I haven't shared this fact with anyone [...]. Now I'm sharing it with you". This narrative measure not only reduces the distance between the protagonist and the audience, but also makes the communication more intimate, especially in the context of what Dully presented. Further narration unveils the aim of this feature. "I have no memory of the operation and never had the courage to ask my family about it. So two years ago I set out on a journey to learn everything I could about my lobotomy”. Indeed, the radio feature consists of the conversations Dully had concerning the procedure.

Dully's narration intersects with his presence as the protagonist of the story. His first interlocutor is Frank Freeman, Walter's son. Frank's image is created in two ways: by means of his statements, his conversation with Howard, and by means of the narrative sequences. Frank talks about his father, about surgical instruments. The narration is consistent with the subject of the conversation, it complements the utterances: "Frank Freeman tells me that the operation was invented in Portugal in 1935. [...] Walter Freeman brought the operation to America and gave it a name, the lobotomy". However, the parts which are the most emotional are those spoken directly by Frank - either when he gets to know the details of Dully's procedure or when he states that he is proud of his father.

The following scene presents Dully talking with Sallie Ellen Ionesco, the first patient of Doctor Freeman, and her daughter Angelene Forester. In the narrative sequence Dully says that Ionesco's procedure was conducted in 1946, and an introduction to the next conversation refers to 1949. The narration thus is chronological. When Dully talks about the late $1940^{\mathrm{s}}$, music contemporary for that time accompanies his words, creating an audio setting ${ }^{20}$. The words from Freeman's archival recording are also portrayed: when the doctor talks about a procedure on a young musician, saxophone music plays in the background. The matching of the background sounds with the character's statements is crucial also on the level of speech: during Doctor Valenstein's speech, one can hear Freeman's recording in the background. When Valenstein finishes his speech with the words: "[lobotomy] spread not only for seriously ill patients but to a lot of people who were not that seriously ill," Freeman's recording comes into focus as the doctor says: "The operator lifts the upper eyelid...".

${ }^{20}$ J. Jankowska, as cited in: K. Klimczak, op. cit., p. 76. 
In his conversation with Carol Noel, a daughter of a woman who was operated on by Freeman, Dully for the first time directly steps out of the role of narrator to the one of protagonist. Immediately after the narrative sequence he greets his interlocutor, his parts are separated with a pause, in which the music referring to the 1950s fades. As Edwin Brys said "music is a demarcation line between the following scenes" ${ }^{21}$, it is a sign for the listener that the action of the broadcast is transferred to modern times. No incidental music accompanies the conversation between Dully and Noel; the woman speaks about life with her mother after the unsuccessful lobotomy. The lack of music emphasises the character of her words: the everyday life, Carol's hardships.

The next scene shows only the protagonist; his roles overlap, his utterances connect and intersect. Dully shows his medical records from years ago: "Mrs Dully came in to talk about her stepson, who is now 12 years old". The next part of the reading serves as a background to the narrative sequence which begins with: "It's pretty much as I suspected". The protagonist continues to read the records, spontaneously commenting on some fragments. Music indicates another narrative sequence, in which Dully talks about a letter he wrote to his father, and he quotes some parts of it. He also points out that My Lobotomy is a project on which he has been working for a long time and only after a year did he find the courage to ask his father about his past.

The conversation with his father is the only one which is not announced in the narrative sequence. Howard says: "I'm here with my Dad. I've waited for over 40 years for this moment". During the conversation the narrative sequences sometimes come into focus. They inform the audience that, even though Dully's father evades responsibility for the procedure, Howard is happy about the reunion and the honest conversation.

Although the encounter with his father was an emotional experience for the protagonist, and a culmination point of a kind on his path to getting to know the details of his procedure, it is the last but one element of the broadcast. The chronological narration leads to the moment where Freeman conducts his last procedure, however, the dialogue between Dully and Anita McGee - Freeman's patient - and her daughter Rebecca Welch is the last conversation in the feature. The conversation with Rebecca allows Dully to find peace as he says that:

"After two years of searching, my journey is finally over. I'll never know what I lost in those 10 minutes with Dr. Freeman. [...] I know my lobotomy didn't touch my soul. I am, at last, at peace".

The action of My Lobotomy is divided into two spheres: the chronological narration conducted by the protagonist tells about his journey, as Dully calls it a journey to find truth. The record of his conversations with the people whom he

\footnotetext{
${ }^{21}$ E. Brys, as cited in: K. Klimczak, op. cit., p. 77.
} 
met along the way is a documentation of this process. It makes the communication more credible, it places it within the contemporary reality and shows the commonness of the issue, with which the protagonist has to deal.

The type of thinking which was used in this work differs from other exemplifications of fiction in artistic reportage. Howard Dully - the protagonist of the radio feature - is an authentic figure. However, the narrative sequences, which at times override the authentic conversations, emphasise the artistic values of the work. The narration, prepared in advance, differs from Dully's spontaneous comments on the recording and from the way he conducts his interviews. Such a way of introducing narration in the work underlines the unreal elements, which are only made authentic through the fact that the narrative sequences were read by the protagonist of the broadcast. This measure allowed me to classify the work as an artistic illustration of a radio documentary.

\section{Conclusion}

As was stated at the beginning, the radio feature as a genre escapes unambiguous definitions and classifications, and scholars' stances differ, both in Poland and all over the world. Polish nomenclature distinguishes the radio feature from the radio reportage, however, in the West these are considered identical. Some Polish scholars compare it to the artistic reportage, however, this is not a claim that is commonly adopted. Press experts perceive a feature as something immeasurably different from what one understands when one thinks of a radio feature.

Disputes referring to the definition of the genre, however, did not stand in the authors' way, as feature broadcasts are common and appreciated on Polish radio stations. On the other hand, the documentary form itself seems to be acknowledged by the audience both in Poland and abroad, and documentary broadcasts are quite popular among the recipients. The diversity of broadcast documentaries gives the listeners an opportunity to choose the form which is most interesting for them. This variety, present in the Polish and foreign radio industry, stems from the popularity of the works which connect truth with fictional elements.

\section{Bibliography}

Bachura J., "Feature - the marriage of Fact and Fiction", in: "Radio - Community, Challenges, Aesthetics", [Print].

Bauer Z., „Gatunki dziennikarskie”, in: „Dziennikarstwo i świat mediów”, ed. Z. Bauer, E. Chudziński, Universitas, Cracow 2010, pp. 143-173.

Budzyński A., „Feature - gatunek otwarty”, Antena 1983, No. 23, p. 14. 
Fischer E.K., "Hoerpiel. Form und Funktion" [on-line], http://www.mediaculture-online.de/ Autoren_A-Z.253+M53913aff3f5.0.html [access:13.03.2013].

Jarisch J., "Was ist eigentlich ein Feature?" [on-line], http://www.yeya.de/journal/faq [access: 4.02.2013].

Kąkolewski K., „Reportaż” [Entry], in: „Słownik literatury polskiej XX wieku”, ed. A. Brodzka et al., Zakład Narodowy im. Ossolińskich, Wroclaw 1993, p. 930-935.

Klimczak K., „Reportaże radiowe o krzywdzie i cierpieniu”, Wydawnictwo Primum Verbum, Lodz 2011.

Koźniewski K., „Rzeczywistość i fikcja”, in: S. Baczyński, A. Kijowski, „Pisma krytyczne”, Państwowy Instytut Wydawniczy, Warsaw 1963, as cited in: K. Wolny-Zmorzyński, A. Kaliszewski, W. Furman, „Gatunki dziennikarskie. Teoria - praktyka - język”, Wydawnictwa Akademickie i Profesjonalne, Warsaw 2006, p. 57.

Pleszkun-Olejniczakowa E., „«Muzy rzadko się do radia przyznają». Szkice o słuchowiskach i reportażach radiowych”, Wydawnictwo Primum Verbum, Lodz 2012.

Pleszkun-Olejniczakowa E., „Reportaż to gra uczuć i emocji. O reportażach radiowych współczesnych twórców Polskiego Radia”, in: „Media studies. Refleksja nad stanem obecnym”, ed. K. Stępnik, M. Rajewski, Wydawnictwo Uniwersytetu Marii Curie-Skłodowskiej, Lublin 2008, p. 365-376.

Tuszewski J., „Paradoks o sławie i dźwięku. Rozważania o sztuce radiowej”, Wydawnictwo Adam Marszałek, Torun 2002.

Wiegner H., „Funkcja form reporterskich w «Programie dla Zagranicy» Polskiego Radia”, Wydawnictwa Radia i Telewizji, Warsaw 1972.

Wolny K., „Reportaż - jak go napisać?”, Fosze, Rzeszow 1996.

http://soundportraits.org/on-air/my_lobotomy/page4.php [access:23.03.2014].

http://soundportraits.org/on-air/my_lobotomy/transcript.php [access:8.06.2013].

http://storycorps.org/about/press-room-news/ [access:23.03.2014].

Natalia Kowalska

\section{The American Broadcast My Lobotomy as an Example of a Radio Feature in the West}

\section{(Summary)}

This article consists of two parts. In the first one, I analyse relations between a reportage and a feature. Differences can be found in the way these notions are defined by scholars in Poland and in Western Europe. Polish radio documentaries are based on authenticity, while in a feature the truth intermingles with fiction. My Lobotomy, by David Isay and Piya Kochhar, serves as an example of a work which presents both authentic characters and some fictional elements. In the second part of the article I focused on the analysis of this American feature. As far as I am concerned, what makes the work most interesting is the relationship between the protagonist's authentic and spontaneous reactions and the read out narrative sequences.

Keywords: radio, feature, radio documentary. 